\title{
Growing Up Entrepreneurial Mindset with Discovery Learning Model Development
}

\author{
B Lena Nuryanti, Eded Tarmedi, Rd. Dian H. Utama, Girang Razati \\ Universitas Pendidikan Indonesia \\ lenanuryanti@upi.edu
}

\begin{abstract}
Entrepreneurship Learning in college should produce graduates to prepare for entrepreneurship. This study seeks to develop a Learning model entrepreneurship using discovery learning. Discovery learning Model defined as a learning process without lesson presented directly, but it is expected to organize their own. The purpose of this study is to describe 1) Discovery Learning Model on Student, 2) Entrepreneurial mindset in students, 3) The amount of influence discovery learning model on the entrepreneurial mindset student. The sampled in this study were 70 students of Business Management Education 2nd grade University of Indonesia. The method used in this research is explanatory survey method with the technique of saturated sample, data analysis techniques used in this study is simple linear regression with SPSS. The findings in this study are as follows: 1) Discovery Learning Model on Student very high, 2) Entrepreneurial mindset in students in the high category 3) Entrepreneurial mindset positively influenced by the discovery learning model with determination coefficient of $18.8 \%$. Based on these results is recommended to provide another research concern discovery learning model with different indicators and different objects.
\end{abstract}

Keywords - Discovery Learning, Growing Up, Entrepreneurial Mindset, Model Development.

\section{INTRODUCTION}

Education basically have two major tasks. First, prepare a generation that has adaptability to environmental expectations. Second, set up them to enable solve the problems in new ways. First task of education, students learn to understand the conditions and environment around them. Second task, encourages students to innovate.[1] There is a reality being faced by the nation that is the problem of unemployment and employment. All this time education has succeeded in making mindset of job seekers generation. Almost all graduates are busy looking for work while jobs are limited.[2]

Mindset created by education, experience and prejudice someone in dealing with something. Good or not someone responding to something is an important matter because it relates to the decision making process. There are two types of human mindset that is the mindset remains include selfishness, the closed nature, self employed, opposed others even feel destined as a lowlife.[3] Conversely another kind of mindset is evolving mindset that emphasizes on optimistic, positive thinking, diligent, hard-working and feel can change something. In business sector, a businessman must have the mindset (Entrepreneurial mindset) can be constructed and designed by an entrepreneur to determine a wise decision.

The mindset of an entrepreneur it is the mindset proactive, creative, innovative because that mindset needed by every entrepreneur to opperate a business.[4] Entrepreneurial mindset can be constructed in various ways, one of which is by learning both inside and outside the classroom. Learning is essentially an attempt to direct students into the learning process so they can obtain learning objectives according to what to expect. Learning should notice individual circumstances students because they will learn.[5]

Education community interest in the future besides the quality of learning process, the results are also good quality, good quality in the academic, qualified in mentoring emotional and spiritual quality. Quality learning, teachers and lecturers are given the freedom to actualize optimal for learning so potential learners can develop. learning model refers to the Four Pillars of Education stated by Delors [6], namely Learning to know, Learning to do, Learning to live together and Learning to live with other and Learning to be.

The educational process can not be separated by the learning process. Learning is an attempt to create conditions conducive to student learning [7]. From This limitation appear process of teaching and learning is the main target in the learning process of target students or students.

Students are individuals differ from each other, have the uniqueness of each are not equal to others. Therefore, learning in universities should notice individual differences of the students, so that learning can actually change the condition of a student who is not knowing to knowing, from not understanding come to understand and less well behaved being good.[8] The real condition of the students like it, during this time received less attention among lecturers. This is evident from the attention of most lecturers tend to notice the class as a whole, not individual or groups of students, so individual differences received less attention. Other symptoms seen in the fact that many lecturers are using the same methods in the learning process.[9]

As usual many lecturer asked the students to retelling, define, describe, and register rather than analyze, draw conclusions, connecting, synthesize, criticize, creating, evaluate, rethink. [10] As a result, many colleges that pass students think superficially, just standing on the surface of the issue, rather than the students is capable of to think deeply and critical thinking in dealing with matter. 
Critical thinking skills is an ability that must be mastered in the learning process in universities. Because critical thinking is one of ability to train students to think more highly. Trained critical thinking to that students have full understanding of both the concept and the thinking process itself to solve problems in real life. Critical thinking is supposed to be one of the learning experience gained by the students, because the critical thinking required in the application of knowledge and will greatly affect student on making decision in the face of real life problems.[11]

Students' critical thinking skills can be improved through learning model which directs students to the daily problems of the environment around. Learning oriented critical thinking skills students need a strategy that is able to stimulate students to develop thinking ability.[12]

Learning that less attention to individual differences and are based on the wishes of lecturers, will be difficult to deliver students toward achievement of learning objectives. These conditions generally occur in conventional learning. The consequences of pedagogical approach is the real gap between students who are intelligent and less intelligent students in achieving the learning objectives.[13] Such conditions result uncompleted the study, so learning system completely neglected. This proves a failure in the learning process in universities.

According to Putu Aditya Between[14], one of the challenges faced by education in Indonesia in the future is a sufficient number of graduates from high school who did not continue their studies (dropout), and many college graduates are not able to apply their knowledge in daily activities. Meanwhile with the globalization, foreign workers would soon enter to Indonesia. Therefore, the Indonesian nation must be able to compete. Indonesian nation must prepare the education sector that can prepare human resources (HR) quality which have independence, ability to work, able to adapt, compete and have life skills and being able to open a business / employment for themselves.

The problem faced is how to prepare educational able to produce graduates is capable to adapt, compete, and have life skills so they can open their own business and be able to face global competition. On the other hand the provision of education should not be far from the needs of society and the potential that exists in society. It is nationally absolutely necessary because the National Education Law on communitybased education that is expected to provide education based on the peculiarities of religious, social, cultural, aspirations and potential public as realization of education and to the community.[15].

Recognizing fact as experts attempt to find and formulate a model of learning that can embrace all the differences that owned by the students. The learning model offered is a learning strategy discovery learning. During learning process is often interpreted as a lecturer explains the learning material and the students listen passively. However have been discovered that the quality of learning will increase if the student in the learning process gained ample opportunity to ask questions, discuss, and actively use knowledge the newly acquired. In this way it is also known that the new knowledge tends to be understood and mastered better.[16]

The role of students and lecturers in the context of active learning is very important.[17] Lecturers play an active role as facilitators who helps facilitate student learning, as a manager who is able to design and implement meaningful learning activities, and manage learning resources needed. Student also involved in the learning process along with lecturers because students are guided, taught and trained exploring, searching, questioning something to investigate in response to a question, manage and deliver the results of placement communicatively. Students are expected to modify the new knowledge accepted by the experience and knowledge have ever received.[18]

Through the discovery learning, students are expected to know and develop the learning capacity and their potential. Additionally, students are fully and consciously be able to use the potential of learning resources contained in the surrounding environment, more trained for initiative, to think in a systematic, critical and responsive, so it can resolve the daily problems through meaningful of information retrieval. Active learning requires educators to work professionally, taught systematically, and based learning principles of effective and efficient. This means that educators can manipulate the learning model implemented systematically and makes the learning process meaningful experience for the students.[19]

Therefore educators in universities must have the ability to take advantage of learning resources in their environment optimally in the learning process, develop new ideas, decrease knowledge gaps student of the college with the knowledge acquired from the society, learn about relevancy and relatedness course science with daily needs in society, develop the knowledge, skills and behaviors college students gradually and completely, giving opportunity to college students to develop optimally in accordance with their capabilities and Applying the principles of active learning.[20]

Discovery learning is assumed to be able to change the mindset college students who previously had egoism, the closed nature, working alone, against other people even feel doomed as a lowlife, becomes developed mindset developed with the intention changed into an entrepreneurial mindset that has developed mindset prioritizes on optimistic, positive thinking, diligent and hard-working and feel can change something.[21]

Based on the description background of research, discovery learning can be viewed as a strategy to improve the entrepreneurial mindset to grow so it can create an entrepreneur, so it seems need to do research with the title "Learning Discovery Model Development To Grow Entrepreneurial Mindset on college students in Business Management Education at University of Education Indonesia"

\section{LITERATURE REVIEW}

\section{A. Discovery Learning}

Gagne in Kokom Komalasari [22] defined learning as a process of behavioral changes including changes in human 
tendency such as attitudes, interests, values and abilities that increase ability to doing various kinds of performance (performance).

The learning process according to Nana Sudjana [23] It is the implementation of the curriculum of an educational institution, so can influence students to achieve a predetermined goal.

The learning process happen if there interaction on part of teachers and learning behavior on the part of students did not happen in one direction but there feedback. Objectives is the meeting point and it is binding and directing activity of both parties. Objectives be assessed and evaluated so find out how far achievement of common goals. Based on the explanation of the learning process is inseparable from teachers and good learning model _, the learning process would go well if the teacher uses the learning model excellent as well. According Suyono and Hariyanto [24] learning model is a major component of the learning process in within there are approaches, strategies, methods, techniques and tactics are systematically into a model to achieve learning objectives.

According Aunurrahman [25] learning model can be defined as a set plan or pattern that can be used to design learning materials and guiding learning activities classroom or in other places that implement learning activities. The learning model will be used by teachers as guidelines that are most consistent with the objectives, materials and supporting facilities in doing duties of teachers to teach. Therefore, it needs to do the selection of appropriate learning models in each of learning conditions.

The implementation of curriculum 2013th, used an approaches refers to deep understanding of student on material was taught. This approach is called a scientific approach is learning lead students to be involved in constructing the concept, law or principle through the stages observe, to question, to reason, to try and communicate.[26]

In learning with curriculum 2013th, there are several models of learning that can be applied, including Problem Based Learning, Project Based Learning, and Discovery learning.

According to Jerome Bruner "Discovery learning can be defined as the learning that takes place when the student is not presented with the subject matter in the final form, but rather is required to organize it himself" [27]. Discovery learning model is to understand the concept, meaning, and relationships, through an intuitive process to finally come to a conclusion[28].

Learning strategy first developed by Jerome Bruner focuses on the ability of learners to find something through the inquiry process (research) in a structured and well-organized. As same as opinion of Masarudin Siregar in Muhammad [29] that the discovery by learning is the learning process to find something new in teaching and learning activities. The learning process can find something when educators prepare in advance a variety of materials to be delivered, then they can make the process of finding themselves various important matters related to difficulties in learning.
Entrepreneurial mindset is a someone-framework _ that is always _ entrepreneurial oriented, preferring to live on the evaders uncertainties, viewed things much simpler than anyone else can only see it as a complex, willing to learn something comes from taking risks. [30]

There are five characteristics of entrepreneurial mindset an entrepreneur according to Mcgraith \& Mc.millan[31], is:

- Have a passion to seek new opportunities True entrepreneur will keep vigilant, always looking for a chance to benefit from changes in ways do business. The greatest effects arise when they created a business model entirely new in the industry. The new business model will revolutionize the amount of revenue and operational activities of all companies the same industry. [32]

\section{- Only pursue the best opportunities}

True entrepreneurs only pursue the best opportunities and avoid fatigue would happen if any selection of existing opportunities should be pursued. Although already rich enough, an entrepreneur remain disciplined limit the number and kinds of business projects that will be done. They strictly control the portfolio of opportunities taken in each stage of development, they are strictly linking strategies of the companies with a large selection of specific projects, rather than spending power is too large for a project not the same as the visions of the company. [33]

- Disciplining yourself to realize opportunities

True entrepreneurs not only be aware of the opportunities that might be explored, but also make sure to be able to realize these opportunities. Some entrepreneurs often record all ideas and opportunities in their notebooks so that a particular action when necessary, they will not run out of ideas. [34]

- Focus on execution of decisions, not only planning

An entrepreneur with entrepreneurial mindset execute the business immediately, they never too long to analyze possible opportunities of an idea. Nevertheless, they are very adaptive, able to change direction following the true opportunity, constantly looking for the best way to make it happen. [35]

- Involves the other ability in the team

True entrepreneur involves a lot of people to realize opportunities, both inside and outside the organization. They create and maintain relationships with a partner relationship than working alone. They exploit the intellectual capability and others to achieve a common goal. [36]

Based on these descriptions can be seen that active learning can influence the entrepreneurial mindset. The paradigm in this study are: 


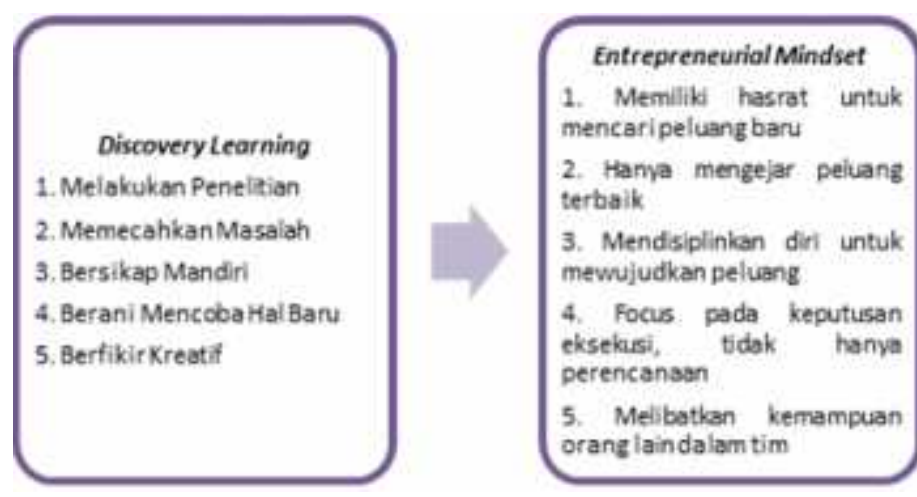

Fig. 1. The paradigm in this study

\section{RESEARCH METHODS}

This study uses an entrepreneurial approach, especially concerning development of _ Discovery Learning Model To Grow Entrepreneurial Mindset. The object of research as independent variables (exogenous) is discovery learning (X) with sub emphasis on the development of learning process analytical and critical thinking skills, students not only learn passively but do relating to the material, emphasis on the exploration of values and demeanor attitudes related to the subject matter, students are required critically, analyze, evaluate, and feedback more quickly will occur in learning process. Then the research object becomes the dependent variable (endogenous) is entrepreneurial mindset (Y) includes passion to seek new opportunities, only pursuing the best opportunities, disciplining yourself to realize opportunities, focus on executions decision, not only the planning, and involve other ability in the team. Objects that as respondents in this research is the college students Business Management Education Universitas Pendidikan Indonesia.

This research was conducted at Universitas Pendidikan Indonesia. Based on the period of the research conducted in the period of less than one year, the research method used is cross sectional method. According to Husein Umar [37] argues that, "The approach is cross sectional research method by studying objects within a certain time or not sustainable in the long term".

Based on the level of explanation and research fields, the type of research is descriptive and verification, with the research method used is explanantory survey. The population in this study were students of Business Management Education Education University of Indonesia with the number $\mathrm{N}=70$. In this study, the sample size is determined through sampling techniques with saturated sample in which all members of the population sampled.

\section{RESULTS AND DISCUSSION}

\section{A. Discussion Descriptive}

\section{1) Discovery Learning Model}

Based on empirical research papers on the implementation of discovery Learning Model in students of Business Management Education at Education University of Indonesia, resulting findings that the indicator model of discovery learning is learning to be independent has contributed high enough for learners to achieve learning discovery learning

\section{2) entrepreneurial Mindset}

Based on empirical research papers concerning entrepreneurial mindset of college students Business Management Education at Education University of Indonesia, resulting findings that dimension only pursuing the best opportunities have contributed sufficiently high to achieve entrepreneurial mindset.

\section{B. Discussion Verifikatif}

Using SPSS, Table I the results obtained regression coefficient are:

$$
\mathrm{Y}=56827.752+0,775 \mathrm{X}
$$

The constant value amounted 56827.752 states that if there is no model of discovery learning, then the magnitude of entrepreneurial mindset amounted 56827.752. Regression coefficient is 0.775 of one unit increase in value means that every discovery learning model will improve the entrepreneurial mindset amounted 0775 the unit value and otherwise, if there is a decrease entrepreneurial mindset, discovery learning model learning entrepreneurial mindset will reduce the unit value amounted 0.775 .

TABLE I. SIMPLE LINEAR REGRESSION MODEL

Coefficients $^{\mathrm{a}}$

\begin{tabular}{|c|c|c|c|c|c|}
\hline \multirow[t]{2}{*}{ Model } & \multicolumn{2}{|c|}{$\begin{array}{l}\text { Unstandardized } \\
\text { Coefficients }\end{array}$} & \multirow{2}{*}{\begin{tabular}{|l|}
$\begin{array}{c}\text { Standardi } \\
\text { zed } \\
\text { Coefficien } \\
\text { ts }\end{array}$ \\
Beta \\
\end{tabular}} & \multirow[t]{2}{*}{$\mathbf{t}$} & \multirow[t]{2}{*}{ Sig. } \\
\hline & $\mathrm{B}$ & Std. Error & & & \\
\hline $\begin{array}{l}\text { (Constant) } \\
\text { Model } \\
\text { Pembelajaran } \\
\text { Discovery } \\
\text { Learning }\end{array}$ & $\begin{array}{l}56827.75 \\
2\end{array}$ & 7797.974 & .433 & 7.288 & .000 \\
\hline
\end{tabular}

a. Dependent Variable: Entrepreneurial Mindset

a. Source: Data Processing, 2015

The relationship between the discovery learning models on entrepreneurial mindset obtained from model of summary described in detail Tabel II below:

The table can be calculated the coefficient of determination of the following:

coefficient of determination $=0.188 \times 100 \%$

coefficient of determination $=18.8 \%$

The results of the calculations above show the magnitude if $\mathrm{KD}$ (coefficient of determination) is $18.8 \%$, which means that the entrepreneurial mindset is influenced by the discovery learning model of learning by $18.8 \%$, while the remaining $81.2 \%$ is influenced by other variables not examined in the study 
TABLE II. MODEL SUMMARY

Model Summary ${ }^{\mathrm{b}}$

\begin{tabular}{|c|c|c|c|c|c|c|c|c|}
\hline \multirow[b]{2}{*}{ Mcdel. } & \multirow[b]{2}{*}{$\mathrm{R}$} & \multirow[b]{2}{*}{ R. Square } & \multirow{2}{*}{$\begin{array}{c}\text { Adjusted R } \\
\text { Square }\end{array}$} & \multirow{2}{*}{$\begin{array}{l}\text { Stt. Error of } \\
\text { the Estimate }\end{array}$} & \multicolumn{4}{|c|}{ Change Statistics } \\
\hline & & & & & $\begin{array}{l}\text { R.Syuere } \\
\text { Chatye }\end{array}$ & F Changs: & df1 $\mathrm{df}$ ? & $\begin{array}{l}\text { Sig. } 5 \\
\text { Charge }\end{array}$ \\
\hline 1 & $133^{2}$ & .189 & 176 & 10381.506 & 188 & 15.727 & 168 & .000 \\
\hline
\end{tabular}

a.Predictors: (Constant), discovery learning b. Dependent Variable: Entrepreneurial Mindset

\section{HYPOTHESIS TESTING}

Table III calculation of the t-test with SPSS obtained tcount amounted 3,966 with significance level of $5 \%$. Compared with t-table value, acquisition count has a number greater than the value $t$ table $(3,966>1,665)$, so decision could be made that the null hypothesis ( $\mathrm{H} 0)$ is rejected and $\mathrm{Ha}$ accepted. This means that there is a positive effect of discovery learning model learning on entrepreneurial mindset.

TABLE III. TEST RESULTS T (T-TEST)

Coefficients $^{\mathrm{a}}$

\begin{tabular}{|c|c|c|c|c|c|}
\hline Model & \multicolumn{2}{|c|}{ Unstandardized Coeftic:ents } & \multirow{2}{*}{$\begin{array}{l}\text { Standardized } \\
\text { Ccefficients } \\
\text { Bcta }\end{array}$} & \multirow[t]{2}{*}{$\mathrm{t}$} & \multirow[t]{2}{*}{ \$ig. } \\
\hline & B & Std. Errer & & & \\
\hline (Constant) & 56827.752 & 7797.974 & & 7.288 & .000 \\
\hline $\begin{array}{l}\text { Model Pembelaiaran } \\
\text { Discoveny I exrning }\end{array}$ & .775 & .195 & 433 & 3.966 & .000 \\
\hline
\end{tabular}

Dependent Variable: Entrepreneurial Mindset

c. Source: Data Processing, 2015

\section{CONCLUSION}

Based on the discussion of theory, research, and testing of linear regression analysis conducted on the effect of active learning on entrepreneurial mindset in college students Business Management Education at Education University of Indonesia can be summed up as follows:

- The study states that, active learning in college students Business Management Education at Education University of Indonesia is at a very high category. This suggests that the discovery learning model in college students of Business Management Education at Education University of Indonesia has been good. It can be seen from the indicators of the highest to the lowest. Indicators obtained the highest score is to be independent with the acquisition of a score of $81.0 \%$. While indicators had the lowest ratings is indicators of creative thinking with a score of $74.7 \%$.

- Results stated that, entrepreneurial mindset in students of Business Management Education at Education University of Indonesia at the high category. This shows that the entrepreneurial mindset of college students Business Management Education at Education University of Indonesia has been good. Characteristics have the highest ratings is only pursuing the best opportunities to gain a score of 1,831 , while the characteristics that have the lowest ratings is focus on execution of the decision, not just planning. 
- The results stated that the discovery learning model positively influences entrepreneurial mindset with the direct influence of $18.8 \%$. This shows that the higher the implementation of active learning, the higher the entrepreneurial mindset

\section{RECOMMENDATION}

- The discovery learning model in college students of Business Management Education at Education University of Indonesia can be improved by increasing the ability of teachers to design discovery learning model in making students more creative thinking with substantial training and education so as to produce students with good learning performance, and be able to creative thinking so that learners can understand a phenomenon or problem from every side not just one or two particular side only.

- Entrepreneurial Mindset of college students Business Management Education at Education University of Indonesia could be improved on aspects of the decision to focus on execution, not just planning. This can be improved by creating a framework, without a clear framework and directed so work performed are also in uncertainty. So it can provide a clear framework, everyone will be able to work effectively. Besides making a framework, to increase its focus on decision execution can be done by setting a target of achieving a standard of success on the work to be carried out.

- The results of this study stated that the discovery learning model positive effect on entrepreneurial mindset, then by doing so the authors recommend to perform discovery learning model is more optimal learning by doing experiments or experiments in the classroom so that the knowledge and skills of students increasingly explore

\section{REFERENCES}

[1] Kairamo K, editor. Education for life: A European strategy. Butterworth-Heinemann; 2014 May 20.

[2] Putu, A, Antara. (2012). Pembelajaran Entrepreneurship Yang Realistik: The Realistic Enterpreneurship Learning. 2012.pp:1.

[3] Sassenberg K, Moskowitz GB. Don't stereotype, think different! Overcoming automatic stereotype activation by mindset priming. Journal of Experimental Social Psychology. 2005 Sep 30;41(5):506-14.

[4] www.kompasiana.com. Akses: 20.15 WIB. Minggu, 25 Oktober 2015.

[5] Stahl G, Koschmann T, Suthers D. Computer-supported collaborative learning: An historical perspective. Cambridge handbook of the learning sciences. 2006;2006:409-26.

[6] Delors, Jacques, et.al. Learning : The Treasure Within, Report to UNESCO of the International Commissions on Education for the Twenty-fisrt Century. 1996. pp: 85-97

[7] Endang Mulyani dkk,. Model Pusat bisnis di SMK dalam Mendukung Pengembangan Entrepreneur Muda Indonesia. 2008.

[8] Keller C, Cernerud L. Students' perceptions of e-learning in university education. Journal of Educational Media. 2002 Jul 1;27(1-2):55-67.

[9] Laurillard D. Rethinking university teaching: A conversational framework for the effective use of learning technologies. Routledge; 2013 Jul 4.
[10] Noel J. Developing multicultural educators. Waveland Press; 2008 Feb 25.

[11] Keeley SM, Browne MN. Asking the right questions: A guide to critical thinking.2007.

[12] Pithers RT, Soden R. Critical thinking in education: A review. Educational research. 2000 Jan 1;42(3):237-49.

[13] Laird TF, Shoup R, Kuh GD, Schwarz MJ. The effects of discipline on deep approaches to student learning and college outcomes. Research in Higher Education. 2008 Sep 1;49(6):469-94.

[14] Putu, A, Antara. Pembelajaran Entrepreneurship Yang Realistik: The Realistic Enterpreneurship Learning. 2012.pp: 4.

[15] Soedijarto. Pendidikan Nasional sebagai wahana Mencerdaskan Kehidupan Bangsa dan Membangun Peradaban Negara-Bangsa , 2000.pp:77.

[16] Darling-Hammond L, Barron B, Pearson PD, Schoenfeld AH, Stage EK, Zimmerman TD, Cervetti GN, Tilson JL. Powerful learning: What we know about teaching for understanding. John Wiley \& Sons; 2015 Jul 15.

[17] Bonwell CC, Eison JA. Active Learning: Creating Excitement in the Classroom. 1991 ASHE-ERIC Higher Education Reports. ERIC Clearinghouse on Higher Education, The George Washington University, One Dupont Circle, Suite 630, Washington, DC 20036-1183; 1991.

[18] Putnam RT, Borko H. What do new views of knowledge and thinking have to say about research on teacher learning?. Educational researcher. 2000 Jan 1;29(1):4-15.

[19] Vescio V, Ross D, Adams A. A review of research on the impact of professional learning communities on teaching practice and student learning. Teaching and teacher education. 2008 Jan 31;24(1):80-91.

[20] Knowles MS, Holton III EF, Swanson RA. The adult learner: The definitive classic in adult education and human resource development. Routledge; 2014 Dec 5.

[21] Skiba D, Barton A. Adapting your teaching to accommodate the net generation of learners. Online Journal of Issues in Nursing. 2006 May $1 ; 11(2)$.

[22] Kokom, Komalasari. Pembelajaran Kontekstual Konsep dan Aplikasi. Bandung: Refika Aditama Machmudah, Ummi. (2008). Active Learning dalam Pembelajaran Bahasa Arab. 2011.pp:2.

[23] Sudjana, Nana. Dasar-dasar Proses Belajar Mengajar. 2002,pp: 1

[24] Suyono \& Hariyanto. Belajar dan Pembelajaran. Teori dan Konsep Dasar.2012, pp: 218.

[25] Aunurrahman. Belajar dan Pembelajaran. 2012, pp: 146.

[26] Berg B1. Methods For The Social, Sciences.2004.

[27] Emetembum.Blogspotpembelajarandiscovery.1986.pp: 103.

[28] Budiningsih.Source: http://ariefhistoria.blogspot.co.id/.2005. pp: 43.

[29] Illahi, Mohammad Takdir. Pembelajaran Discovery Strategy \& Mental Vocational Skill. 2012, pp: 30.

[30] McGranth, R. G., \& MacMillan, I. (2000). The Entrepreneurial Mindset: Strategies for Continously Creating Opportunity in an Age of Uncertainly. 2000, pp: 2.

[31] McGranth, R. G., \& MacMillan, I. (2000). The Entrepreneurial Mindset: Strategies for Continously Creating Opportunity in an Age of Uncertainly. 2000, pp: 3.

[32] Sandy, Wahyudi. Entrepreneurial Branding and Selling: Road Map Menjadi Entrepreneur Sejati. 2012. pp: 105.

[33] Sandy, Wahyudi. Entrepreneurial Branding and Selling: Road Map Menjadi Entrepreneur Sejati. 2012. pp: 105.

[34] Sandy, Wahyudi. Entrepreneurial Branding and Selling: Road Map Menjadi Entrepreneur Sejati. 2012. pp: 106.

[35] Sandy, Wahyudi. Entrepreneurial Branding and Selling: Road Map Menjadi Entrepreneur Sejati. 2012. pp: 106.

[36] Sandy, Wahyudi. Entrepreneurial Branding and Selling: Road Map Menjadi Entrepreneur Sejati. 2012. pp: 106.

[37] Husein, Umar. 2008. Metode Riset Bisnis. 2008, pp: 45. 